\title{
The Role of Motivation, Discipline, Salary, and Islamic Work Ethics on Increasing Employee Performance
}

\author{
Ikhsan Naufal Dwilaksana ${ }^{1}$, Rosana Eri Puspita ${ }^{1}$, Mochlasin ${ }^{1}$, Adamu Abubakar \\ Muhammad $^{2}$ \\ ${ }^{1}$ Faculty of Islamic Economics and Business, IAIN Salatiga, Indonesia \\ ${ }^{2}$ Religious Studies, Federal University of Kashere Gombe State, Nigeria
}

\begin{abstract}
This study aims to determine how strong the influence of motivation, discipline, salary, and IWE (Islamic Work Ethic) on employee performance (a case study at Wanabiprint Digital Printing Salatiga). The method of data collection was done through distributing questionnaires to Wanabiprint employees. Samples were taken as many as 50 respondents. The results of the $t$ test indicate that motivation has no effect on employee performance with a significance value of $0.305>0.05$ and $t$ count $1.038<t$ table 2.014, discipline has no effect on employee performance with a significance value of $0.158>0.05$ and $t$ count $1.437<t$ table 2.014 , salary has no effect on employee performance with a significance value of $0.775>$ 0.05 and $t$ count $0.287<\mathrm{t}$ table 2.014, while IWE (Islamic Work Ethic) affects employee performance with a significance value of $0.00<0.05$ and t count 4,580 > ttable 2,014. Furthermore, motivation, discipline, salary and IWE (Islamic Work Ethic) have a simultaneous effect on employee performance with a significance value of $0.000<0.05$ and an $f$ value of $18.050>\mathrm{f}$ table 2.57 on employee performance. So that these variables have an effect simultaneously.
\end{abstract}

Keywords: Motivation, Discipline, Salary, IWE, Employee Performance

\section{Introduction}

Humans, as perfect creatures, are the main source that underlies operational activities. Human resources have a very important role in carrying out the company's plans to achieve its vision, mission, and goals. Because in carrying out operational activities, the problems faced are not only about the means of production, capital, and the environment. However, human resources are also one of the problems that companies must resolve at any time to obtain optimal employee performance results. This underlies in general that employee performance is the main factor in achieving a business organization's success and public service (Lubis, 2015).

Employee performance is the spearhead in a company. Both good and bad companies are seen from how well the employees perform in performing Standard Operating Procedures. How to analyze employee performance in implementing Standard Operating Procedures can be seen from the following factors, abilities, work skills, motivation, work 
ethic, infrastructure, comfort, environment, work conditions, managerial, security, and competence (Simanjuntak, 2005). This should be a big concern for every company to analyze how employee performance problems occur.

Salary is one of the motivating means for improving the quality of employee performance to increase the level of productivity at work (Triani, 2019). The company and employees have an engagement that both have a role in exercising their rights and obligations. Therefore, the harmony between the two parties must always be integrated through the existence of fair reciprocity.

To carry out good reciprocity, Islam as the religion of mercy has taught mankind to carry out business activities according to the Al-Qur'an and As-Sunnah to achieve the best performance. From an Islamic perspective, companies are encouraged to apply the IWE (Islamic Work Ethic) system. This aims to get the company's Falah (goodness) reflected in the increasing form of happiness, luck, success, and prosperity both physically and mentally (Aqbar, 2020).

The Islamic work ethic application will lead employees to always be motivated to do their job well. This will be reflected in shaping employee discipline. A discipline is a form of training oriented to improve and shape knowledge, attitudes, and good behavior. Employees voluntarily try to work cooperatively with other employees by improving their work performance. This discipline orientation will lead to more organized employee performance (Sajangbati, 2013).

On the other hand, in building motivation, the company has a big role in providing a stimulus to its employees. The burden placed on employees will be easier and more successful in overcoming the problems (Murty, 2012).

Based on the description above, the author is keen to research the influence of motivation, discipline, salary, and IWE (Islamic Work Ethic) on employees' performance. A case study will be done in the Wanabiprint Digital Printing Company.

\section{Literature Review}

\subsection{Motivation}

All humans have basic needs, which are the main goal of fulfilling their needs. Therefore humans are encouraged to be motivated to fulfill their needs. The needs that are the basis of motivation, according to Maslow, are physiological, the need for security, social needs, selfesteem needs, and self-actualization needs (Maslow, 1954).On the other hand, motivation is defined as the whole process of giving encouragement or stimulation to employees so that they are willing to work willingly without being forced (Kadarisman, 2013). The organization will be successful in carrying out its programs if the people who work in the organization can carry out their duties properly following their respective fields and responsibilities. In carrying out these tasks, employees need to be given direction and encouragement so that their potential can be transformed into achievements that benefit the organization (Susanti, 2019). To build motivation for employees, leaders must know and understand motivational and maintenance factors (Herzberg, 2012).

\subsection{Discipline}

Discipline is a process that corrects or punishes subordinates for violating the rules or procedures that apply in the order of regulation (Simamora, 1997). Work discipline can be 
reflected in employees' attitudes to company rules. According to disciplinary experts, several problems must be controlled because discipline can positively affect efficiency and effectiveness in achieving company goals (Chika Saputri, 2020).

The factors that can affect employee discipline (Sutrisno, 2009). First, the size of the company in providing compensation to employees. Second, the presence and absence of exemplary figures are shown by the leadership of the company. Third, the existence and absence of clear rules or regulations for use by employees. Fourth, the leader's courage in making decisions. Fifth, the presence and absence of comprehensive supervision from the leadership. Sixth, the presence and absence of leadership attention to employees. Seventh, Creating a corporate culture that supports discipline enforcement.

\subsection{Salary}

Salary or wages can be interpreted as payments provided to labor workers for employers' physical or mental services. The total amount determined as a substitute for the workforce's services includes certain periods or conditions (Sadono, 2005). Meanwhile, in the book Human Resource Management in Sharia Financial Institutions. Salary or wages are fair and decent remuneration is given to workers for their services in achieving organizational goals (Soleh, 2020). The purpose of providing wages or remuneration is to maintain employees' existence, maintain employee morale, and maintain the company's survival, which will ultimately benefit the community. The concept of wages in an Islamic perspective is inseparable from a sense of fairness. Ibnu Taimiyah's thinking relates the level of wages, which is equivalent to a basic principle regulated using the same rules with an equivalent price, meaning that wages in normal conditions are determined by bargaining between both parties. Islam provides a wage solution based on justice and honesty and protects the interests of employers and workers. According to Islam, wages must be given properly and properly while keeping in mind Islam's teachings.

\subsection{IWE (Islamic Work Ethic)}

IWE (Islamic Work Ethic) can be defined as a set of moral principles that can distinguish what is right from wrong in the context of an Islamic point of view. IWE (Islamic Work Ethic) is a work orientation and work approach as a virtue in human life. IWE (Islamic Work Ethic) itself is based on the Koran, the Prophet's teachings which state that hard work causes sins to be forgiven, and the legacy of four Islamic Caliphs (Rizk, 2008). Islamic work ethics is a human behavior or habit that humans often carry out in carrying out workers sourced from good morals and come from Islamic faith or belief, a basic life attitude of the Islamic religion's teachings (Mustakim, 2018).

There are theories regarding Islamic work ethics (Hana, 2015). First, laziness is the enemy of the Islamic religion. Second, dedicating oneself to work optimally is a virtue. Third, working properly according to existing regulations can be beneficial for oneself and others. Fourth, being fair and wise in the work environment is a necessity for mutual welfare. Fifth, work to meet personal needs and provide benefits to the ummah, including contributing to society as a whole. Sixth, one must contribute as much as possible to do the job to the best of his ability. Seventh, work is not an end in itself but a process in self-development. Eighth, life is not going to mean if we were not working. Ninth, Being unemployed and wasting time is a waste of time. 


\subsection{Employee Performance}

The theory of employee performance was put forward by George Poulos, who is often called the Path-Goal Theory, which states that performance is a function of the facilitating process and the inhibiting process. The basic principle of this theory suggests that high performance is a path to satisfy needs (goal) particular, it will follow that path as a bridge to get his wish or a function of the level of needs which concerned shall/facilitating process (Yohana, 2017).

Employee performance results from the implementation of work both in quantity and quality in carrying out the duties and responsibilities that have been given to each employee (Lubis, 2015). Employee performance is one of the main factors that affect organizational progress. The higher or, the better the employee's performance, the easier the organizational goals will be achieved, and vice versa if the employee performance is low. Performance is something that cannot be separated from the organization (Triastuti, 2018).

Performance is usually equated with the work of an employee, to achieve good performance, a good element is human resources even though the planning has been well and neatly arranged if the person or personnel who do it is not qualified and does not have high morale, then the arranged plan will be in vain (Hasibuan, Jasman Saripuddin, 2019).

\section{Hypothesis Development}

Yohana's research on motivation concluded that the motivation variable positively and significantly affects employee performance (Yohana, 2017). In another study, it is suggested that motivation has a significant positive effect on employee performance (Sudibya, 2012) So, the first hypothesis can be built.

H1: Motivation has a positive and significant effect on employee performance.

In one of the studies conducted, Hidayat stated that discipline positively affects employee performance (Hidayat, 2012). This is reinforced by Mandey's research which shows that discipline has a significant positive effect and partial (Mandey, 2014).

H2: Discipline has a positive and significant effect on employee performance.

As for other research conducted by Subianto, it is clear that salary has a significant effect on employee performance (Marianus Subianto, 2016). Likewise, research conducted by Derendehe on employee performance at PT. ASKES (PERSERO) Manado branch states that salaries significantly affect employee performance (Darendehe, 2013).

H3: Salary has a positive and significant effect on employee performance

Other research conducted by Amaliah suggests that IWE (Islamic Work Ethic) has a significant effect on employee performance (Amaliah, 2013). Besides, in other research literature conducted by Rusyanti on Hotel employees in Solo, it is concluded that Islamic Work Ethics affect employee performance (Rusyanti, 2019).

H4: IWE (Islamic Work Ethic) has a positive and significant effect on employee performance.

Research conducted by Susanto suggests that work motivation has influenced employee performance, job satisfaction has influenced employee performance, and work discipline influences employee performance (Susanto, 2019). According to Muhzinat's research, 
motivation and Islamic work ethic significantly affect employee performance (Muhzinat, 2018). This is reinforced in research conducted on Mavin foundation educators who argue that motivation and work discipline positively affect employee performance (Sunarsi, 2018).

H5: Motivation and discipline have a positive effect on employee performance.

From the results of the analysis of research conducted by previous researchers and the elaboration of the theory on each variable, a framework of thought can be formulated as follows:

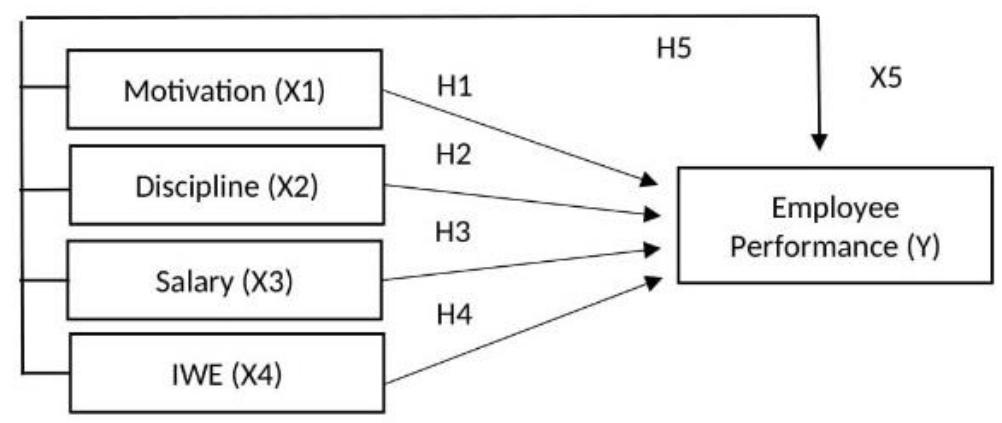

Fig 1. Research Model

\section{Research Method}

This type of research used in this research is quantitative research. Quantitative research is research used to examine specific populations or samples; sample collection techniques are carried out randomly, data collection using research instruments, quantitative or statistical analysis to test existing hypotheses (Sugiyono, 2017).

The research instrument in this study is questionnaires. The questionnaire is an instrument for data collection, where participants or respondents fill out questions or statements given by the researcher (Sugiyono, 2015). The research is about motivation, discipline, salary, and IWE (Islamic Work Ethic) on employee performance, case study on Wanabiprint Digital Printing.

The population is the entire area of the object and research subject that is determined to be analyzed. Then the researcher concludes (Bawono, 2006). Meanwhile, according to (Sugiyono, 2017). the population is a generalization area consisting of objects or subjects with certain quantities and characteristics determined by researchers to study and then draw conclusions. The population in this study were all employees who worked at Wanabiprint Digital Printing Company.

The sample is the object or research subject chosen to represent the entire population. This aims to save time and costs. The sample's determination must be careful because the conclusions generated are the population's conclusions (Bawono, 2006). Samples are also usually defined as part of the number and characteristics of the population. The sampling technique that the researcher will do is using purposive sampling, even though the researcher does not know the population size. Purposive sampling is a sampling technique with certain considerations (Sugiyono, 2016). This is the respondent criteria. First, respondents are employees of Wanabiprint Digital Printing. Second, employees who are at Wanabiprint in Kalimangkak, Wanabiprint in Pemotongan and 


\section{$A T \overline{C E B}$ Annual International Conference \\ on Islamic Economics and Business, 2021}

Wanabiprint in Ambarawa.The appropriate sample size in research is 30 to 500 (Roscoe,1975). If the study is multivariate (including multiple regression analysis), then the number of sample members is ten times the number of variables (dependent + independent) studied. In this study, the number of samples taken using the sample members is at least ten times the number of variables (dependent + independent) studied. Hence, the number of samples in this study was 50 samples (Sugiyono, 2016).

Table 1. Gender

\begin{tabular}{|c|c|c|c|}
\hline No. & Gender & $\begin{array}{c}\text { Number of } \\
\text { Respondents }\end{array}$ & Percentage \\
\hline 1 & Man & 40 & $80 \%$ \\
\hline 2 & Female & 10 & $20 \%$ \\
\hline & Total & 50 & $100 \%$ \\
\hline
\end{tabular}

Source: Primary data processed in 2020

Based on the table above, it can be seen that the percentage of male respondents in this study was $80 \%$, and the female gender was $20 \%$.

Table 2. Age of Respondents

\begin{tabular}{|c|c|c|c|}
\hline No. & Age & $\begin{array}{c}\text { Number of } \\
\text { Respondents }\end{array}$ & Percentage \\
\hline 1 & $17-22$ years old & 28 & $56 \%$ \\
\hline 2 & $23-28$ years old & 12 & $24 \%$ \\
\hline 3 & $29-34$ years old & 4 & $8 \%$ \\
\hline 4 & $35-40$ years old & 4 & $2 \%$ \\
\hline 5 & $41-46$ years old & 1 & $2 \%$ \\
\hline 6 & $47-52$ years old & 1 & $0 \%$ \\
\hline 7 & $53-58$ years old & 0 & $0 \%$ \\
\hline 8 & $>58$ years old & 0 & $100 \%$ \\
\hline
\end{tabular}

Source: Primary data processed in 2020

Based on the table above, it can be seen that the age of the respondents used as the sample of this study was dominated by most of the ages between 17-22 years old with a percentage of 56\%, then followed by ages 23-28 years old at 24\%, then aged 29-34 years old and 35-40 years old who have a percentage of $8 \%$ each, the age of 41-46 years old and 4752 years old show the percentage of $2 \%$ each, then the last category of age 53-58 years old and $>58$ years old has no respondents, so the percentage is $0 \%$. 


\section{$A I C \quad$ Annual International Conference \\ on Islamic Economics and Business, 2021}

Table 3. Length of Work

\begin{tabular}{|c|c|l|c|c|}
\hline No. & & Length of work & Number of Respondents & Percentage \\
\hline 1 & & $1-6$ months & 20 & $40 \%$ \\
\hline 2 & & $6-12$ months & 3 & $6 \%$ \\
\hline 3 & & $1-2$ years & 13 & $26 \%$ \\
\hline 4 & $2-5$ years & 8 & $16 \%$ \\
\hline 5 & & $5-8$ years & 4 & $8 \%$ \\
\hline 6 & $8-11$ years & 2 & $100 \%$ \\
\hline \multicolumn{2}{|c|}{ Total } & 50 & $4 \%$ \\
\hline
\end{tabular}

Source: Primary data processed in 2020

Based on the table above, we can analyze the length of work of the respondents as follows. 1-6 months has the largest percentage, namely $40 \%, 1-2$ years $26 \%$, 2-5 years $16 \%$, 5-8 years $8 \%, 6-12$ months $6 \%$, then $8-11$ years $4 \%$.

Table 4. Validity Test

\begin{tabular}{|c|c|c|c|c|c|}
\hline No. & Variable & Item & R Count & R Table & Information \\
\hline \multirow{5}{*}{1} & Motivation & $\mathrm{X} 1.1$ & $0.716 * *$ & 0.2732 & Valid \\
\hline & & $\mathrm{X} 1.2$ & $0.726 * *$ & 0.2732 & Valid \\
\hline & & $\mathrm{X} 1.3$ & $0.825 * *$ & 0.2732 & Valid \\
\hline & & $\mathrm{X} 1.4$ & $0.627 * *$ & 0.2732 & Valid \\
\hline & & $\mathrm{X} 1.5$ & $1,000 * *$ & 0.2732 & Valid \\
\hline \multirow{5}{*}{2} & Discipline & $\mathrm{X} 2.1$ & $0.740 * *$ & 0.2732 & Valid \\
\hline & & $\mathrm{X} 2.2$ & $0.752 * *$ & 0.2732 & Valid \\
\hline & & $\mathrm{X} 2.3$ & $0.686 * *$ & 0.2732 & Valid \\
\hline & & $\mathrm{X} 2.4$ & $0.533 * *$ & 0.2732 & Valid \\
\hline & & $\mathrm{X} 2.5$ & $0.781 * *$ & 0.2732 & Valid \\
\hline \multirow{5}{*}{3} & Salary & X3.1 & $0.739 * *$ & 0.2732 & Valid \\
\hline & & X3.2 & $0.718 * *$ & 0.2732 & Valid \\
\hline & & $\mathrm{X} 3.3$ & $0.774 * *$ & 0.2732 & Valid \\
\hline & & X3.4 & $0.782 * *$ & 0.2732 & Valid \\
\hline & & $\mathrm{X} 3.5$ & $0.757 * *$ & 0.2732 & Valid \\
\hline 4 & IWE & X4.1 & $0.527 * *$ & 0.2732 & Valid \\
\hline
\end{tabular}




\begin{tabular}{|c|c|c|c|c|c|}
\hline & ( Islamic Work Ethic ) & $\mathrm{X} 4.2$ & $0.529 * *$ & 0.2732 & Valid \\
\hline & & $\mathrm{X} 4.3$ & $0.635 * *$ & 0.2732 & Valid \\
\hline & & $\mathrm{X} 4.4$ & $0.832 * *$ & 0.2732 & Valid \\
\hline & & $\mathrm{X} 4.5$ & $0.678 * *$ & 0.2732 & Valid \\
\hline \multirow{5}{*}{5} & Employee performance & $\mathrm{Y} 1$ & $0.713 * *$ & 0.2732 & Valid \\
\hline & & Y2 & $0.468 * *$ & 0.2732 & Valid \\
\hline & & Y3 & $0.704 * *$ & 0.2732 & Valid \\
\hline & & Y4 & $0.600 * *$ & 0.2732 & Valid \\
\hline & & Y5 & $0.662 * *$ & 0.2732 & Valid \\
\hline
\end{tabular}

Source: Primary data processed in 2020

Based on the table above, it can be seen that the calculated r-value of each of the five variables is greater ( $>$ ) than the $\mathrm{r}$ table. Thus, all statements and questions, including the variables, are valid and can support this research.

Table 5. Reliability Test

\begin{tabular}{lcc}
\hline \multicolumn{1}{c}{ Variable } & Cronbach's Alpha & Information \\
\hline Motivation & 0.780 & Reliable \\
\hline Discipline & 0.725 & Reliable \\
\hline Salary & 0.809 & Reliable \\
\hline IWE ( Islamic Work Ethic) & 0.638 & Reliable \\
\hline Employee performance & 0.606 & Reliable
\end{tabular}

Source: Primary data processed in 2020

From the reliability test results, it was found that all the values of the variables $\mathrm{X} 1, \mathrm{X} 2$, $\mathrm{X} 3, \mathrm{X} 4$, and $\mathrm{Y}$ resulted in a Cronbach's Alpha value $>0.6$. So it can be concluded that all the instruments in this study are reliable.

\section{Result And Discussion}

\subsection{Result}

Based on the motivation $t$ test test $(\mathrm{X} 1)$ has a significance value of $0.305>0.05$ and $t$ count $1.038<\mathrm{t}$ table 2.014, so it can be said that motivation has no significant effect on employee performance.

Discipline (X2) has a significance value of $0.158>0.05$ and $t$ count $1.437<\mathrm{t}$ table 2.014, so it can be concluded that discipline does not have the power to have a significant effect on employee performance.

Salary (X3) has a significance value of $0.775>0.05$ and $t$ count $0.287<2.014$, so it can be concluded that salary has no significant effect on employee performance. 
IWE (Islamic Work Ethic) (X4) has a significance value of $0.00<0.05$ and $t$ count $4.580>\mathrm{t}$ table 2.014, so it can be concluded that IWE (Islamic Work Ethic) has a significant and significant effect on employee performance.

Based on the results of the F test, it can be seen that the variables of motivation (X1), discipline (X2), salary (X3), and IWE (Islamic Work Ethically) (X4) simultaneously against $\mathrm{Y}$ are $0.000<0.05$ and the $\mathrm{F}$ value is $18.050>\mathrm{F}$ table 2.57 , so it can be concluded that H5 is accepted which means there is a positive influence, motivation (X1), discipline (X2), salary (X3), and IWE (Islamic Work Ethic) (X4) simultaneously on Y.

The summary for the results of calculating the five hypotheses above is as follows.

Table 5. Coefficient of Determination and Adjusted R Square, Result of t-test, and F test

\begin{tabular}{|c|c|c|c|c|c|}
\hline & Motivation & Discipline & Salary & IWE & $\begin{array}{c}\text { Employee } \\
\text { performance }\end{array}$ \\
\hline \multicolumn{6}{|l|}{$\begin{array}{c}\text { Adjusted Determinant } \\
\text { Coefficient and R Square }\end{array}$} \\
\hline $\mathrm{R}$ & .148 & .209 & .036 & .523 & .785 \\
\hline R2 & .607 & .614 & .454 & .729 & .616 \\
\hline Customized R Square & 24.3 & 34.0 & 7.9 & 71.74 & .582 \\
\hline \multicolumn{6}{|l|}{ Results of the t-test } \\
\hline \multicolumn{6}{|l|}{ Beta Standard Coefficient } \\
\hline $\mathrm{T}$ & 1,038 & 1,437 & .287 & 4,580 & \\
\hline Sig. & .305 & .158 & .775 & $.000 *$ & \\
\hline \multicolumn{6}{|l|}{ F Test Results } \\
\hline $\mathrm{F}$ & 27,955 & 29,030 & 12,444 & 54,415 & 37,443 \\
\hline Sig & $.000 *$ & $.000^{*}$ & $.001 *$ & $.000 *$ & $.000 *$ \\
\hline
\end{tabular}

* Significant (Sig. <0.05)

Source: Primary data processed in 2020

\subsection{Discussion}

Motivation has no significant effect on employee performance. This happens because of a work culture with a family system that is already attached to the team, besides that the company provides various bonuses such as turnover targets, absenteeism, best employees, lunch, and even monthly basic needs. so that employees feel valued by the company which in the end they are motivated and provide better quality performance without having to be given special motivational training. The results of this study are supported by previous research on the Effect of Leadership Style, Motivation, and Work Discipline on Employee Performance With an Understanding of Islamic Work Ethics concluded that motivational variables do not significantly affect employee performance (Indiyati, 2017).

Discipline has a positive and insignificant effect on employee performance. This happens because the employees comply with the company's rules and regulations in carrying out all existing regulations. In addition, the awareness of employees to carry out SOP (Standard Operating Procedure) has a high initiative to always carry out activities according to the time schedule. this is also based on a long-running company regulation regarding actions for anyone who is not disciplined with several penalties such as salary deductions, room cleaning, and moral sanctions from friends. So this is what shapes employees to be disciplined and in the end this will become a habit without having to be directed about discipline.This study's results are supported by one of the studies entitled, which was conducted that discipline does not affect employee performance (Saripuddin, 2017). 


\section{$\mathrm{AIC} \overline{\overline{I E B}}$

Salary has no significant effect on employee performance. This happens because the employees feel happy and proud to be working at Wanabiprint, this is the main basis for employees to be passionate about work and the income given by the goal is the main thing. This context can be seen through the strength of a very close togetherness and family system so that employees feel comfortable in carrying out all their activities. On the other hand, employees have been given a salary with a basic salary system and a turnover bonus in accordance with the company's income. This encourages employees to continue to push for better performance. So it is only natural that salary does not affect employee performance. Therefore, the company must increase the company's income or turnover so that employee salaries are increasing and performance is getting better. This is in line with research conducted on companies in Indonesia Batam City which suggests that salary has no significant effect on employee performance (Maifanda, 2013).

IWE (Islamic Work Ethics) has a positive and significant effect on employee performance. This is based on the strength of belief formed by employees to do their work solely to worship Allah SWT. acknowledge and believe that Allah will provide sustenance to each of His creatures and uphold the Islamic principles contained in the Qur'an and AsSunnah. The Wanabiprint company has also implemented an Islamic work system, including regulations the joint briefing continued with prayers, dhuha prayers, fardhu prayers in congregation, and no blank notes were given to consumers. Thus the company demands to always reach the value of blessing. Therefore, the company must increase the strength of its spiritual values in operational activities so that employees can improve the quality of their performance. This is in line with research conducted at a hotel in Solo which concluded that IWE (Islamic Work Ethic) has an effect on employee performance (Rusyanti, 2019). The Islamic work ethic is an orientation that is formed to influence the involvement and participation of adherents in the workplace with Islamic concepts.

This shows that these variables simultaneously or together can affect the level of employee performance. This is based on the strong correspondence between variables so that it can improve the quality of employee performance if the company can apply the variables simultaneously. generated by the motivation of each individual has an attachment to the desire of employees to carry out their activities with discipline. The discipline formed creates employee comfort in working so that employees do not demand to get a large salary because the company has provided satisfactory quality and a salary that is deemed to be in accordance with their needs. In addition, the application of Islamic values has also provided a tremendous influence for employees to carry out work activities sincerely and intended solely to get the pleasure of Allah SWT. with an orientation to worship Him. So that these variables can simultaneously affect the quality of employee performance at Wanabiprint. In accordance with one of the studies at the sales division of PT Rembaka stated that work motivation has an influence on employee performance, job satisfaction has an influence on employee performance, and work discipline has an influence on employee performance (Susanto, 2019b). Furthermore, research conducted on Sambal Special Waroeng stated that Islamic motivation and work ethic significantly influence employee performance (Muhzinat, 2018). In addition, in research the performance of Mavin foundation educators who argue that motivation and work discipline have a positive effect on performance (Sunarsi, 2018). 


\section{$\triangle \mathrm{T} \overline{I E B}$ Annual International Conference \\ on Islamic Economics and Business, 2021}

\section{Conclusion And Suggestions}

\subsection{Conclusion}

In this study, the condition of employee performance at the Wanabiprint company is influenced by the IWE (Islamic Work Ethic) variable and the variable simultaneously. This is an impetus for the company to continue to improve these two variables so that they can be applied in standard operating procedures (SOP), so that the company hopes that the company will continue to improve the quality of its employees. As for the other variables, namely, motivation, discipline and salary which do not have an effect on increasing employee performance, all applicable rules regarding these three variables must be maintained, because with these results it shows that the company has been able to form a good character for employees, especially in the standard of giving Motivation, Discipline and Salary that has been running. On the other hand, all the variables studied simultaneously have an effect on improving the quality of employee performance. Therefore, the Wanabiprint company can improve employee performance by stimulating or designing a system by encouraging these variables.

\subsection{Suggestion}

Suggestions for the Wanabiprint company, the company must continue to improve integrated and structured motivation through several activities carried out by the company to stimulate employees to improve the quality of their performance. Second, discipline as a process of character building must be further improved. This will be reflected in the attitude of employees who obey the rules that apply in the company so that it has a good impact on performance. Third, the salary given must be adjusted to the size of the business or the hard work of employees working for the company. Fourth, the company provides better worship facilities to carry out worship activities. This encourages employee performance to work as much as possible. Wanabiprint companies can improve employee performance by stimulating and designing a system by pushing these four variables simultaneously.

For further researchers, you should continue to look for new variables that can be studied regarding employee performance. If more variables studied, it will add novelty to increase knowledge horizons, especially related to employee performance.

\section{Reference}

Amaliah, I., Julia, A., \& Riani, W. (2013). Pengaruh dari Nilai-Nilai Islam terhadap Kinerja Kerja. MIMBAR, Jurnal Sosial Dan Pembangunan, 29(2), 165. https://doi.org/10.29313/mimbar.v29i2.394

Chika Saputri, S. (2020). Pengaruh Lingkungan Kerja, Budaya Kerja Dan Kedisiplinan Kerja Terhadap Kinerja Karyawan Pada Pt Epson Batam. Jurnal Ekonomi Bisnis, 6(1), 133147.

Darendehe, A. (2013). Gaji, Kepemimpinan, Dan Sikap Rekan Kerja Pengaruhnya Terhadap Kinerja Karyawan Pt. Askes (Persero) Cabang Manado. Jurnal Riset Ekonomi, Manajemen, Bisnis Dan Akuntansi, 1(4), 22-30.

Hana, M. M. (2015). Pengaruh Etika Kerja Islam Dan Kepuasan Kerja Terhadap Kinerja Karyawan. Jurnal Ekonomi Syariah, 3(2), 118-132.

Hanafi, B. D., \& Yohana, C. (2017). Pengaruh Motivasi, Dan Lingkungan Kerja, Terhadap 
Kinerja Karyawan, Dengan Kepuasan Kerja Sebagai Variabel Mediasi Pada Pt Bni Lifeinsurance. Jurnal Pendidikan Ekonomi Dan Bisnis (JPEB), 5(1), 73-89. https://doi.org/10.21009/jpeb.005.1.6

Hasibuan, Jasman Saripuddin, B. S. (2019). Pengaruh Motivasi Kerja Dan Disiplin Kerja Terhadap Kinerja Karyawan. SEMNAS Multidisiplin Ilmu, 2(1). https://doi.org/10.31227/osf.io/9frzv

Khaerull Aqbar, Azwar Iskandar, A. H. D. Y. (2020). Konsep al-Falah dalam Islam dan Implementasinya dalam Ekonomi. BUSTANUL FUQAHA: Jurnal Bidang Hukum Islam, 1(3), 516-531. https://doi.org/10.36701/bustanul.v1i3.206

Latief, B. (2012). Faktor-Faktor Yang Mempengaruhi Kinerja Karyawan PT. Mega Mulia Servindo Di Makasar. Manajemen Dan Akuntansi, 1(2), 61-70.

Lubis, M. S. (2015). Pengaruh Iklim Organisasi Dan Komitmen Organisasi Terhadap Pembentukan Organizational Citizenship Behavior (Ocb) Karyawan Dalam Rangka Peningkatan Kinerja. E-Jurnal Apresiasi Ekonomi, 3(2), 75-84.

Mandey, S., \& Sahangggamu, P. (2014). Pengaruh Pelatihan Kerja, Motivasi, Dan Disiplin Kerja Terhadap Kinerja Karyawan Pada Pt. Bank Perkreditan Rakyat Dana Raya. Jurnal Riset Ekonomi, Manajemen, Bisnis Dan Akuntansi, 2(4), 514-523. https://doi.org/10.35794/emba.v2i4.6359

Marianus Subianto 1. (2016). Pengaruh Gaji Dan Insentif Terhadap Kinerja Karyawan Pada Pt . Serba Mulia Auto. E-Journal Administrasi Bisnis, 4(3), 698-712.

Mekel, M. I. T., A., P., \& Sendow. (2014). Disiplin Kerja, Motivasi Dan Kompensasi Pengaruhnya Terhadap Kinerja Karyawan Pada Pt. Bank Sulut Cabang Calaca. Emba, 2(2), 1594-1606.

Muhzinat, Z. (2018). Pengaruh Motivasi Kerja Dan Etos Kerja Islam Terhadap Kinerja Karyawan Pada Waroeng Spesial Sambal. Universitas Islam Indonesia Yogyakarta.

Munadjat, B. M., Tumanggor, M., \& Oktrima, B. (2019). Pengaruh Kedisiplinan Kerja Terhadap Kinerja Karyawan Pada Pt. Subur Makmur Sentosa Cabang Cikupa Tangerang. JURNAL SEMARAK, 2(1), 64-69. https://doi.org/10.32493/smk.v2i1.2666

Murty, W. A., \& Hudiwinarsih, G. (2012). Pengaruh Kompensasi, Motivasi Dan Komitmen Organisasional Terhadap Kinerja Karyawan Bagian Akuntansi (Studi Kasus Pada Perusahaan Manufaktur Di Surabaya). The Indonesian Accounting Review, 2(02), 215. https://doi.org/10.14414/tiar.v2i02.97

Mustakim, A. (2018). Pengaruh Etika Kerja Islam Terhadap Kinerja Pekerja Di Rumamh Sakit Isla, Puewodadi. Skripsi.

Rizk, R. R. (2008). Back to basics: An Islamic perspective on business and work ethics. Social Responsibility Journal, 4(January), 246-254. https://doi.org/10.1108/17471110810856992

Rusyanti, W. (2019). Analisis Pengaruh Islamic Work Ethic, Employee Engagement, Dan Pengalaman Kerja Terhadap Kinerja Karyawan Hotel Di Solo. In Skripsi.

Sadono, S. (2005). Mikroekonomi Teori Pengantar. Raja Grafindo Persada.

Sajangbati, I. A. (2013). Motivasi, Disiplin, Dan Kepuasan Pengaruhnya Terhadap Kinerja Pegawai Pt. Pos Indonesia (Persero) Cabang Bitung. Jurnal EMBA: Jurnal Riset Ekonomi, Manajemen, Bisnis Dan Akuntansi, 1(4), 667-678. https://doi.org/10.35794/emba.v1i4.2750

Saripuddin, J., \& Handayani, R. (2017). Pengaruh Disiplin Dan Motivasi Terhadap Kinerja Karyawan Pada Pt . Kemasindo Cepat Nusantara Medan Jasman Saripuddin Universitas Muhammadiyah Sumatera Utara Rina Handayani Alumni Fakultas Ekonomi Universitas Muhammadiyah Sumatera Utara. Kumpulan Jurnal Dosen Universitas Muhammadiyah Sumatera Utara, 420-429. 


\section{$\triangle \mathrm{IC} \overline{I E B} \quad$ Annual International Conference \\ on Islamic Economics and Business, 2021}

Soleh, K. (2020). Pengaruh Pemberian Upah, Budaya Kerja Islami Dan Religiusitas Terhadap Kinerja Pegawai Dengan Kepuasan Kerja Sebagai Variabel Intervening (Studi Pada Perusahaan Kabupaten Semarang) Oleh:gama islam negeri salatiga 2020. TESIS.

Sudibya, I. G. A., \& Utama, I. W. M. (2012). Pengaruh Motivasi, Lingkungan Kerja, Kompetensi, Dan Kompensasi Terhadap Kepuasan Kerja Dan Kinerja Pegawai Di Lingkungan Kantor Dinas Pekerjaan Umum Provinsi Bali. Jurnal Manajemen, Strategi Bisnis Dan Kewirausahaan, 6(2), 173-184.

Sunarsi, D. (2018). Pengaruh Gaya Kepemimpinan, Motivasi Dan Disiplin Kerja Terhadap Kinerja Pendidik Yayasan Marvin. Jurnal Ilmiah Ilmu Manajemen, 5(1), 1. https://doi.org/10.32493/inovasi.v5i1.y2018.p1-18

Susanto, N. (2019a). Pengaruh Motivasi Kerja, Kepuasan Kerja, dan Disiplin Kerja Terhadap Kinerja Karyawan Pada Divisi Penjualan PT Rembaka. Agora, 7(1), 6-12.

Susanto, N. (2019b). Pengaruh Motivasi Kerja, Kepuasan Kerja, Dan Disiplin Kerja Terhadap Kinerja Karyawan Pada Divisi Penjualan Pt Rembaka. Agora Vol. 7, No. 1 (2019), 7, No.1, 6-12.

Triani, M., \& Andrisani, E. (2019). Analisis Pengaruh Jumlah Penduduk Dan Upah Terhadap Penawaran Tenaga Kerja Di Indonesia. Jurnal Geografi, 8(1), 49. https://doi.org/10.24036/geografi/vol8-iss1/568

Triastuti, D. A. (2018). Pengaruh Lingkungan Kerja, Kompetensi Dan Iklim Organisasi Terhadap Kinerja Pegawai. Journal of Management Review, 2(2), 203. https://doi.org/10.25157/jmr.v2i2.1796

Yanne Aldi, F. S. (2019). Pengaruh Stress Kerja Dan Motivasi Kerja Terhadap Prestasi Kerja Karyawan Pada Pt. Frisian Flag Indonesia Wilayah Padang.

Zainul Hidayat, MM \& Muchamad Taufiq, M. (2012). Pengaruh Lingkungan Kerja dan Disiplin Kerja serta Motivasi Kerja Terhadap Kinerja Karyawan Perusahaan Daerah Air Minum (PDAM) Kabupaten Lumajang. Jurnal WIGA, 2(1), 79-97. https://doi.org/10.33373/dms.v7i2.1702 